\title{
Interpreting Topographic Map Evidence Related to Northeast Nebraska Barbed Tributaries and Drainage Routes, USA
}

\author{
Eric Clausen ${ }^{1}$ \\ ${ }^{1}$ Independent Researcher, Jenkintown, PA, USA \\ Correspondence: Eric Clausen, 100 West Ave D-17, Jenkintown, PA 19046 USA. E-mail: \\ eric2clausen@gmail.com
}

Received: May 9, 2018

doi:10.5539/jgg.v10n2p66

\author{
Accepted: May 16, 2018 \\ Online Published: May 30, 2018 \\ URL: http://dx.doi.org/10.5539/jgg.v10n2p66
}

\begin{abstract}
Northeast Nebraska barbed tributaries include north-oriented streams flowing to the south-oriented Missouri River and south-oriented streams flowing to the north-oriented Missouri River tributaries. Detailed topographic maps were used to determine how these northeast Nebraska drainage routes originated. A giant south-oriented supraglacial melt water river is interpreted to have sliced an ice-walled and bedrock-floored canyon into a decaying ice sheet's surface where eastern South Dakota's east-facing Missouri Escarpment and west-facing Prairie Coteau escarpment are now located and to have flowed from that canyon's mouth across northeast Nebraska while South Dakota's north-facing Pine Ridge Escarpment is interpreted to be the south wall of a large east-oriented valley that was eroded headward across immense southeast-oriented ice-marginal melt water floods which had originally flowed across northeast Nebraska. Prior to Missouri River valley headward erosion these two different immense melt water floods created and then flowed across a low relief and low gradient northeast Nebraska topographic surface. Present day northeast Nebraska topography developed when the deep south-oriented Missouri River valley and its south-oriented tributary valleys eroded headward into this low relief and low gradient topographic surface. As the deep Missouri River valley eroded headward it beheaded shallow south-oriented flood flow channels supplying water to new and actively eroding south-oriented Missouri River tributary valleys and water on north ends of the beheaded channels reversed flow direction to move toward the much deeper Missouri River valley. Water still moving in south directions adjacent to these reversed flow channels was then captured leading to development of south-oriented tributaries to the north-oriented streams.
\end{abstract}

Keywords: diverging and converging channels, glacial melt water floods, James River, Missouri Escarpment, Missouri River, Prairie Coteau Escarpment, Pine Ridge Escarpment

\section{Introduction}

The Missouri River flows in an east, southeast, and then south direction around the Nebraska northeast corner (see figure 1). North-oriented streams with south-oriented tributaries join that east-, southeast- and south-oriented Missouri River segment. How did north-oriented barbed tributaries to the south-oriented Missouri River originate and how did south-oriented barbed tributaries to those north-oriented barbed tributaries form? Northeast Nebraska is directly to the south of where the south-oriented James River joins the east-, southeast-, and south-oriented Missouri River. Downstream from the James River the Missouri River flows in a much wider valley than in the upstream region. The south-oriented James River originates in central North Dakota and after flowing in an east direction turns to flow in a south direction into and across eastern South Dakota before reaching the much larger Missouri River. In eastern South Dakota the south-oriented James River flows on a lowland floor located between the east-facing Missouri Escarpment and the west-facing escarpment bounding the Prairie Coteau upland. Between the Missouri Escarpment and the Missouri River is the Missouri Coteau, which like the Prairie Coteau upland is covered by collapsed or stagnation moraines while glacially deposited sediments found on the escarpment faces and on the James River lowland floor are quite different. In addition South Dakota's north-facing Pine Ridge Escarpment is located to the west of where the James River joins the Missouri River. What relationship, if any, exists between northeast Nebraska's barbed tributaries, the wider Missouri River valley downstream from the James River, the South Dakota escarpments, and South Dakota's collapsed or stagnation moraine regions? 


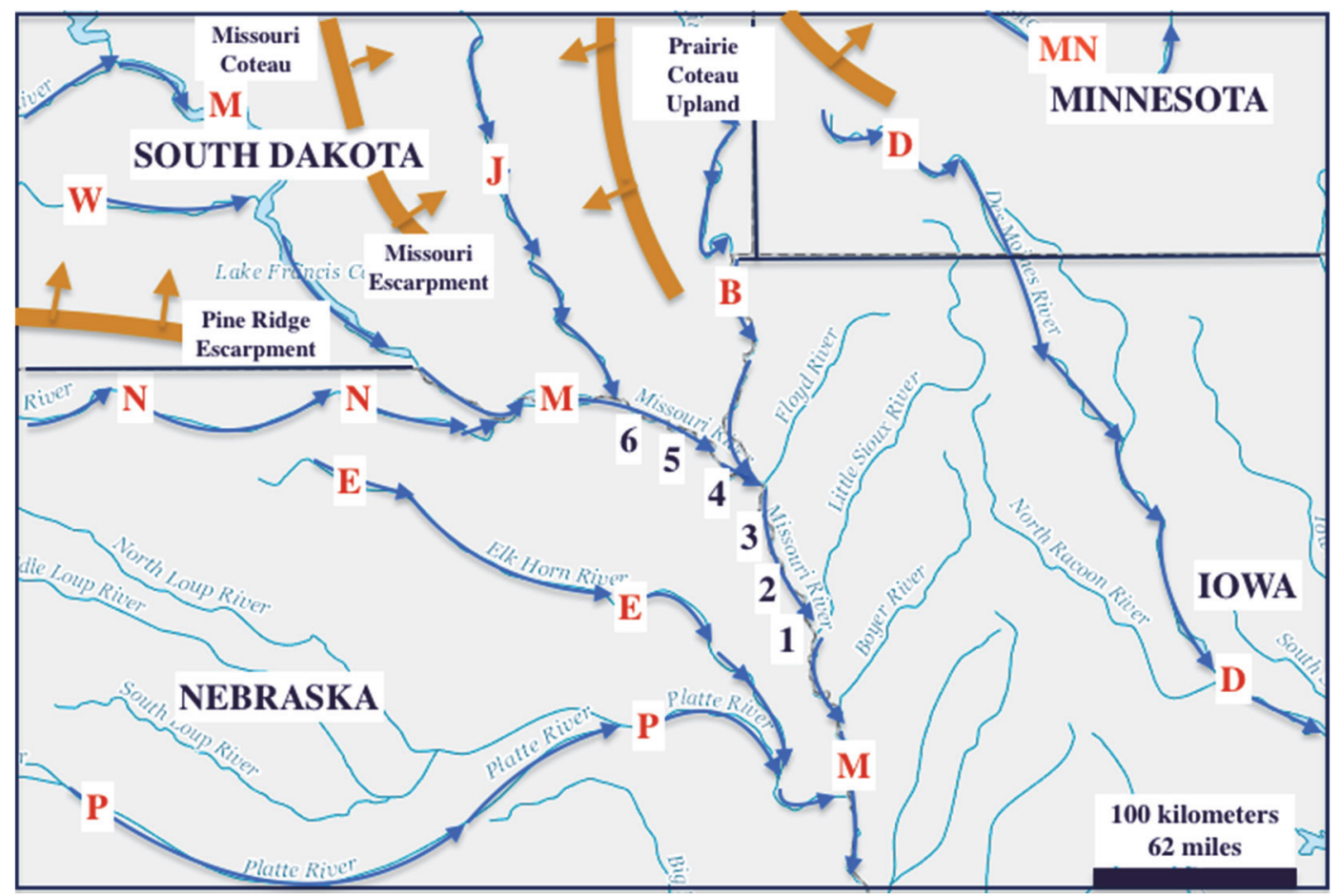

Figure 1. Modified map from United States Geological Survey (USGS) National Map website showing escarpments (brown) and drainage routes (blue) and locations identified in the text

The Missouri Escarpment and escarpments surrounding the Prairie Coteau are components of a much larger escarpment network extending north from figure 1 across North Dakota and into southern Canada. These escarpments typically separate upland regions capped by collapsed or stagnation moraines from broad intervening lowlands now covered by thinner glacial deposits suggesting a different type of ice sheet. While the west- and northeast-facing Prairie Coteau escarpments converge and end to the north of figure 1 the east-facing Missouri Escarpment and adjacent Missouri Coteau can be traced for more than 1000 kilometers from southern South Dakota northward into central North Dakota and then in a northwest direction into Saskatchewan and Alberta. The somewhat different north-facing Pine Ridge Escarpment is located to the south and west of recognized glaciated regions. To the west of figure 1 the Pine Ridge Escarpment extends westward into Wyoming where it is known as the Hat Creek Breaks.

The 1000-kilometer long Missouri Escarpment and adjacent Missouri Coteau end in southern South Dakota and do not continue southward into northeast Nebraska, which is located directly to the south of where the James River joins the Missouri River. Northeast Nebraska drainage patterns are completely different from south-oriented drainage patterns in the James River lowland to the north. Northeast Nebraska streams flow in north directions to join the east-, southeast-, and south-oriented Missouri River while most tributaries to the south-oriented James River flow in south directions. Figure 1 uses a modified map from the United Geological Survey (USGS) National Map website to illustrate where the east-, southeast- and south-oriented Missouri River flows around Nebraska's northeast corner. Blue arrows emphasize some major regional drainage routes and directions and red letters identify the emphasized rivers as follows: B-Big Sioux River, D-Des Moines River, E-Elkhorn River, J-James River, MMissouri River, MN-Minnesota River, N-Niobrara River, and P-Platte River. Black numbers identify locations where north-oriented tributaries described in the text join the south-oriented Missouri River as barbed tributaries and are identified as follows: 1-Elm Creek, 2-South Blackbird Creek, 3-Omaha Creek, 4-Pigeon Creek and Elk Creek, 5- South Creek-Aowa Creek, and 6-Bow Creek. The Missouri River forms otherwise unmarked (by straight black lines) South Dakota-Nebraska and Nebraska-Iowa border segments and the Big Sioux River forms the otherwise unmarked South Dakota-Iowa border segment.

\section{Previous Work}

Burchett et al (1988) mapped northeast Nebraska bedrock geology including bedrock topography underneath glacially deposited sediments. Clay till and glaciofluvial deposits from at least two glacial ages were interpreted 
to cover the underlying bedrock surface and loess lies on top of the glacial deposits. The bedrock map shows Tertiary age Ogallala Group (silt, sand, sandstone, gravel, and conglomerate) in higher western and northern areas with Cretaceous Niobrara Formation (chalk, limestone, and shale) beneath it. Under the Niobrara Formation and the east-oriented Missouri River valley segment is the Cretaceous Carlile Shale (shale, limestone, and sandstone). Beneath the Carlile Shale and generally nearer to the south-oriented Missouri River valley segment are, from top to bottom, Cretaceous age Greenhorn Limestone (limestone and calcareous shale), Granerous Shale (calcareous and carbonaceous shale), and Cretaceous age Dakota Group (sandstone and shale). Isopleths on their map show the pre-Pleistocene bedrock surface does not always reflect the present day surface topography and suggests at least some present day valleys are eroded into the overlying glacial tills and loess.

Wayne $(1985,1987)$ is one of the few geomorphologists to have published interpretations of at least some eastern Nebraska drainage patterns and he begins by describing previously published evidence in Stanley and Wayne (1972) suggesting that prior to the Pleistocene, streams flowing from the eastern slopes of the rising Rocky Mountains drained eastward across Nebraska and built a broad alluvial slope (now the Miocene Ogallala Group surface with the Arikaree formation underneath) in the region known as the High Plains (found to the south of the Pine Ridge Escarpment rim). Wayne also cites evidence described in earlier publications that prior to the Pleistocene ice advances the Missouri River flowed northeastward across central Canada (e.g. Alden, 1932) and the Platte River flowed across Iowa. Wayne further suggests the first continental glacier blocked the northeast-oriented Missouri River and forced it to develop a southward route and during subsequent glaciations the Missouri River and eastward-flowing rivers across the Dakotas and Nebraska were repeatedly diverted with the Missouri River finally fixed in its present valley after the third major glaciation.

Wayne $(1985,1987)$ interprets eastern Nebraska southeast-oriented streams to have originated as ice-marginal drainage routes and cites work by Horberg and Anderson (1956) and Aber (1982) to suggest the Prairie Coteau upland split Pleistocene ice sheets as they flowed southward through the Dakotas and Minnesota into two lobes with Horberg and Anderson describing Wisconsin glacial lobes and Aber describing earlier Pleistocene glacial lobes. Wayne suggests during the earlier glaciation the two lobes coalesced in eastern Nebraska and "After the ice had disappeared from the state [Nebraska], though, the tip of a lobe from the James River tongue extended across the [Missouri] river... and left a concentric series of small ice-marginal streams as it melted." He also suggests the south- and southeast-oriented streams that "bend abruptly northward... describe a series of arcs that surely mark successive retreatal positions of an ice lobe that crossed the Missouri trench around Yankton, South Dakota" (Yankton is located near where the James River joins the Missouri River). Wayne goes on to note that no direct evidence in the form of tills suggests Wisconsin ice entered Nebraska, however he uses indirect evidence including the above mentioned drainage patterns to suggest the ice sheet "must have crossed and blocked the Missouri River at least briefly."

Mason et al. (2006) describe eastern Nebraska loess deposits in the region to the south of this paper's study region where they use thickness and grain size to suggest the loess was transported westward from the wide Missouri River valley into Nebraska (while their publication does not say so loess deposits in this paper's study region are probably similar). Based on loess deposit ages they suggest the Missouri River valley must have been in existence as early as 500-600 ka. Mason et al also suggest the Todd Valley (an abandoned valley where the Platte River now turns from an east-northeast direction to a south-southeast direction and located to the south of this paper's study region) may have been abandoned at about the same time as the Missouri River valley was eroded, but they are unable to provide a connection between the two events. They also take issue with some of Wayne's ice-marginal drainage route interpretations by stating, "there is little stratigraphic or geomorphic evidence for the [late Wisconsin] ice sheet advance into Nebraska that Wayne (1987) proposed" to explain the Todd Valley abandonment.

Wayne is by no means the only investigator to have used drainage route positions when identifying possible former ice-margin positions. For example, to the north of figure 1 in central North Dakota the James River and the Sheyenne River originate in the same region on the Missouri Escarpment slope and flow in east and south directions nearly adjacent to and parallel to each other in the region to the east of the Missouri Escarpment before the Sheyenne River makes a U-turn in southeast North Dakota to join the north-oriented Red River with its water eventually reaching Hudson Bay while the James River continues to flow in a south direction to enter South Dakota and reach the Missouri River. Brophy and Bluemle (1983) interpret the east- and south-oriented James and Sheyenne River drainage routes to have originated as ice-marginal streams when the last Wisconsin ice sheet retreated northward. They interpret eastward and northward sloping pre-glacial topography to have enabled the Sheyenne River to turn in an east and northeast direction and to flow into what at that time was Glacial Lake Agassiz, while the adjacent James River continued to flow in a south direction across eastern South Dakota.

Even if some northeast Nebraska drainage routes originated along ice margins as Wayne proposes the region's 
numerous south-oriented barbed tributaries to north-oriented barbed tributaries to the south-oriented Missouri River suggest a much more complex drainage history. Headward erosion of deeper stream valleys capturing water flowing in shallower stream valleys, or stream captures, is the mechanism that usually explains how barbed tributaries develop. However, Bishop (1995) and other researchers have argued stream captures do not normally occur and for that reason are rare geomorphic events. Such arguments and the large number of probable stream capture events observable on detailed topographic maps led Pederson (2001) to argue groundwater sapping, not surface water, may be the responsible stream capture mechanism. Unfortunately Pederson, who spent much of his career in Nebraska, only described one Nebraska example and that example was of "freezing groundwater in a vertical river bank that led to the dislodging of frozen bank material in meter-sized blocks" and does not explain how groundwater sapping can produce south-oriented barbed tributaries to a north-oriented oriented barbed tributary to the south-oriented Missouri River.

The literature rarely addresses the regional escarpment origins and those rare discussions give few details. Bluemle (1991) says, "Before they were glaciated the Turtle Mountains [an isolated escarpment-surrounded upland straddling the North Dakota-Manitoba border] and Prairie Coteau [upland] were erosional outliers - probably low mesas - of Cretaceous and Tertiary sandstone formations that stood above the surrounding plain. ... No really satisfactory explanation has been proposed to explain the presence and prominence of the Missouri Escarpment." Bluemle goes on to say "The Missouri Escarpment is considered to mark the boundary between the Great Plains, on the west, and the Central Lowland, on the east. It also separates an extensive area of hummocky collapsed moraine, the Missouri Coteau, from the smoother Glaciated Plains to the east. In places, the rise in elevation across the Missouri Escarpment is as much as 650 feet [198 meters] in a distance of one or two miles [1.6 or 3.2 kilometers], but a less pronounced rise of about 300 to 500 feet [91 to 152/ meters] in a distance of two to three miles [3.2 to 4.8 kilometers] is more common." Thornbury (1965) notes "the north-facing Pine Ridge Escarpment separates the Missouri Plateau from the High Plains section to the south. This southward-receding escarpment, which is capped with the Arikaree formation and underlain by the weak Brule shale, is a prominent topographic feature which locally attains heights of 1000 feet [305 meters].” In other words the escarpment origins are uncertain and poorly explained.

Most previous investigators including R.F. Flint (1955, 1971), who conducted a major study of eastern South Dakota glacial history, treated the bedrock surface (under glacially deposited sediments) in North and South Dakota and adjacent regions to reflect the late Tertiary topographic surface and assumed Pleistocene ice sheets and melt water from those ice sheets did not significantly alter the late Tertiary topography. White (1972) challenged that assumption and proposed a "deep erosion by continental ice sheets" hypothesis. White's hypothesis while logically consistent with the easily eroded nature of most Northern Plains region bedrock, was strongly criticized when several workers, including Sugden (1976), argued, among other things, the present day Missouri River drainage basin upstream from central South Dakota originally had drained in a north direction to the Labrador Sea. Maps illustrating this hypothesized pre-glacial north-oriented drainage system (named the Bell River system) can be found in Sears (2013), McMillan (1973), and other publications and evidence for the north-oriented drainage system exists in the form of abandoned valleys now partially filled with glacially transported debris.

Recently Clausen (2017a, 2017b, 2018a), who views topographic map evidence from the perspective of a new and different geomorphology paradigm, challenged the Bell River drainage system pre-glacial age and argued northand northeast-oriented western South and North Dakota Missouri River tributary valleys eroded headward across massive southeast-oriented ice-marginal melt water floods in sequence from the southeast to the northwest. In another paper Clausen (2018b) describes his new paradigm and shows how southeast-oriented floods of probable continental ice sheet origin deeply eroded the northeast Wyoming Powder River Basin area and also deeply eroded areas to the north of the Pine Ridge Escarpment. He suggests headward erosion of deep north-oriented valleys from the ice sheet location across the southeast-oriented ice-marginal floods was possible because at least one North American ice sheet created (by deep erosion and crustal warping) and occupied a deep "hole" and eventually melted in a such a way that valleys could erode headward from space in that deep "hole" being opened up as the ice sheet melted. Headward erosion of the north-oriented valleys diverted southeast-oriented ice marginal melt water floods into ice-walled and bedrock-floored canyons that had been sliced into the decaying ice sheet's surface. He suggests this diversion of melt water floods eventually changed the climate and caused water flowing in north directions onto the decaying ice sheet's floor to freeze and eventually to fill the ice-walled and bedrock-floored canyon network with frozen water. The result was a new and much thinner ice sheet consisting of previous ice sheet remnants surrounded by wet based frozen melt water floods.

Clausen suggests the Missouri Escarpment is what remains of an ice-walled and bedrock-floored canyon's west and southwest wall and the west-facing Prairie Coteau escarpment is a segment of that ice-walled and bedrock- 
floored canyon's east wall with the James River lowland between those escarpments being where the southoriented supra-glacial melt water river that sliced the ice-walled and bedrock-floored canyon into the decaying ice sheet's surface once flowed. Collapsed or stagnant moraines areas on the Missouri Coteau and Prairie Coteau areas and the more northerly escarpment bounded upland regions represent locations where decaying ice sheet remnants once existed and the wet-based frozen melt water floods filled the intervening ice-walled and bedrock-floored canyon areas. The northeast Nebraska area discussed in this paper according to these interpretations is where massive volumes of south-oriented melt water emerged from the James River lowland ice-walled and bedrockfloored canyon's mouth and merged with immense southeast-oriented ice-marginal melt water floods that were eroding the north-facing Pine Ridge Escarpment westward as the south wall of an east-oriented valley where the large southeast-oriented ice-marginal floods were removing that valley's north wall almost as fast as the valley was being eroded.

\section{Research Method}

The study reported here is one component of the much larger Missouri River drainage basin landform origins research project. Larger project research notes in blog format can be found at geomorphologyresearch.com. The larger project consisted of studying detailed topographic maps covering the entire Missouri River drainage basin to determine how drainage divides within and surrounding the Missouri River drainage basin originated. Larger project results suggest Missouri River drainage basin valleys eroded headward along and across immense southeast-oriented floods in an identifiable sequence usually from the southeast to the northwest, but upstream from the figure 1 map area and this paper's study region headward erosion of north- and northeast-oriented valleys captured the large southeast-oriented floods and diverted the floodwaters in a north direction, again in an identifiable sequence from the southeast to the northwest. The study reported here focuses on the northeast Nebraska region and with the exception of information taken from cited references does not attempt to address other regions.

This study used detailed topographic maps from the United States Geological Survey (USGS) National Map website, although during the larger study the northeast Nebraska region was first studied using large mosaics of detailed hard copy topographic maps and was subsequently restudied several years later using National Geographic TOPO software and detailed digital topographic maps. In each case the studies reached the same conclusions. This study began by looking for north-oriented tributaries flowing as barbed tributaries to the south-oriented Missouri River and for south-oriented tributaries flowing to those north-oriented Missouri River tributaries. The assumption was next made that these present day north-oriented Missouri River tributaries originated as shallow south-oriented drainage routes and were then beheaded and reversed by headward erosion of the much deeper Missouri River valley.

Drainage divide areas at south ends of the north-oriented tributary drainage basins were inspected to identify where shallow south oriented drainage routes had once flowed from what are today north-oriented drainage basins into the south-oriented Missouri River tributary valleys. Multiple closely spaced gaps notched into those drainage divides were interpreted to have been eroded by diverging and converging south-oriented flood eroded channels and floor elevations of those gaps were compared with drainage divide high point elevations to determine depths and floor elevations of the south-oriented flow channels. Similarities of drainage divide high point elevations were used to suggest shallow diverging and converging south-oriented flood flow channels had been eroded into an extremely low relief and low gradient topographic surface that had once extended across the entire region. Drainage divide high points further suggested this low relief and low gradient topographic surface had sloped very gradually in southeast and south directions. Deposition and erosion by immense south-oriented continental ice sheet melt water floods were considered to be a more likely process to have produced the low relief and low gradient topographic surface than a retreating ice sheet margin.

\section{Results}

\subsection{Elm Creek-Silver Creek and Blackbird Creek-Bell Creek Drainage Divide Areas}

Elm Creek is a relatively short north- and northeast-oriented stream seen in figure 2 that joins the south-oriented Missouri River at Decatur, Nebraska (just to the north of figure 2). Several southeast-oriented tributaries and several north-oriented tributaries (including north-oriented Lone Tree Creek) join the north-oriented Elm Creek valley. To the south of the Elm Creek headwaters is the south-oriented Silver Creek drainage basin with Silver Creek joining the south-oriented Missouri River near Tekamah, Nebraska (just to the south of figure 2). While primarily a south-oriented drainage basin Silver Creek does have north- and northeast-oriented tributaries only partially seen in figure 2. To the west of the north-oriented Elm Creek drainage basin and in the northwest corner of figure 2 South Blackbird Creek makes an abrupt U-turn as it turns from flowing in a south-southeast direction 
to flow in a north direction. To the north of figure 2 South Blackbird Creek flows in a north-northeast direction to join Blackbird Creek at the edge of the south-oriented Missouri River valley. To the south of the South Blackbird Creek U-turn is south-oriented Bell Creek, which flows in a south direction to join the south-southeast oriented Elkhorn River. Finally just to the west of figure 2 the larger south-southeast-oriented Logan Creek valley drains to the Elkhorn River.

Explaining the south-oriented Silver Creek valley in the context of either Wayne's retreating glacial ice lobes interpretation or Clausen's massive south-oriented melt water flood interpretation is relatively easy. Explaining the north-oriented Elm Creek valley is another matter. Assuming Wayne's interpretation is correct, and if the ice lobe advances did not destroy the pre-existing north-oriented Elm Creek valley, a retreating ice sheet margin should have dammed the north-oriented valley and created an ice-dammed lake, yet the detailed topographic maps show no evidence for such a lake. Assuming Clausen's hypothesis is correct the north-oriented Elm Creek valley cannot predate the massive south-oriented melt water floods and at first it may be difficult to visualize how a southoriented flood can erode a north-oriented valley.

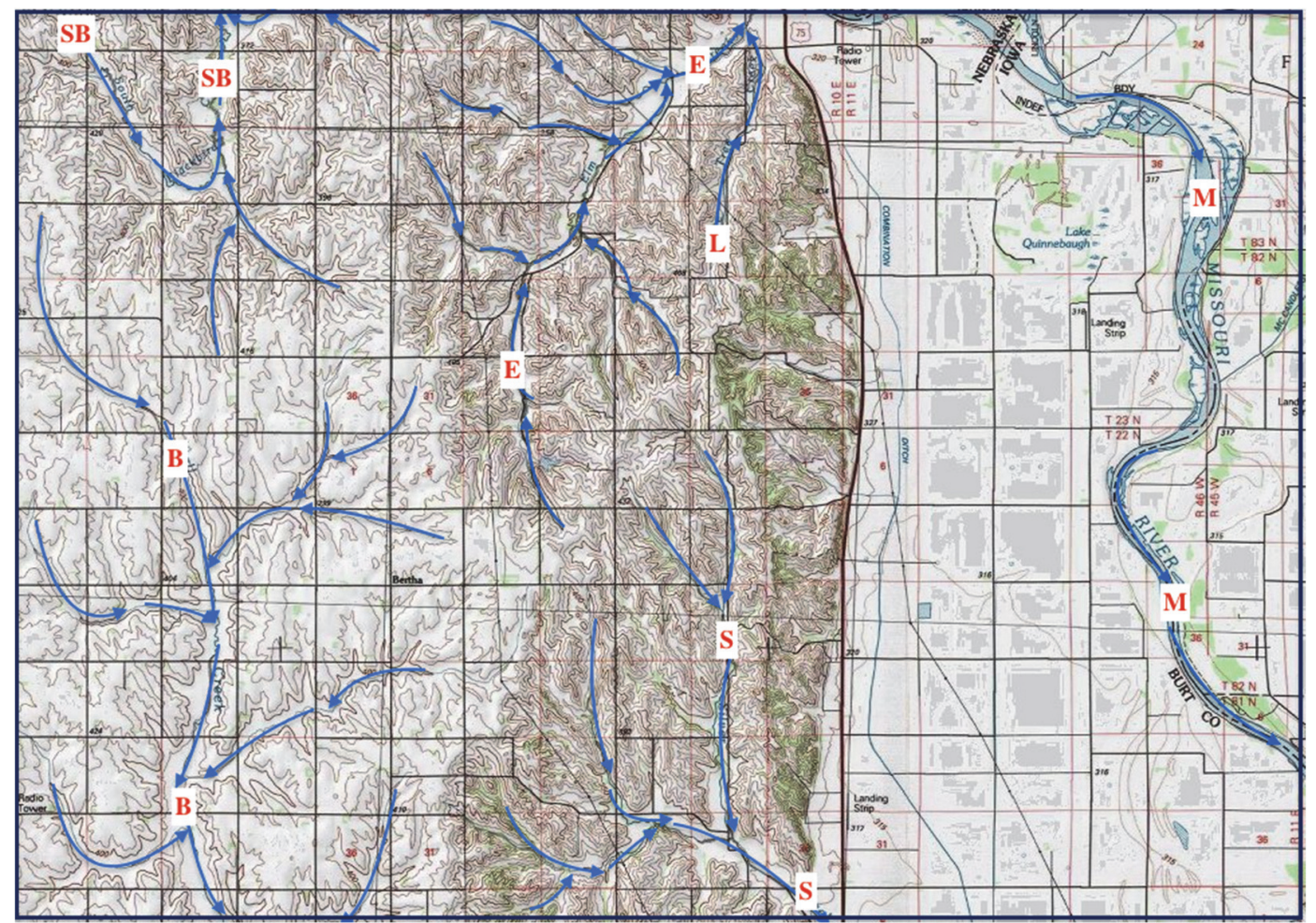

Figure 2. Modified map from USGS National Map website showing the Elm Creek-Silver Creek and South Blackbird Creek-Bell Creek drainage divide areas. Blue arrows emphasize drainage routes and directions and are identified as follows: M-Missouri River, B-Bell Creek, E-Elm Creek, S-Silver Creek, and SB-South Blackbird Creek. Sides of squares in the grid are one mile (1.6 kilometers) long. The contour interval is 10 meters (33 feet). Figure 2 is located at location number 1 in figure 1

A north-oriented valley like the Elm Creek valley could result if massive south-oriented floods were moving across the low relief and low gradient topographic surface extending across the entire area seen in figure 2 at the same time as the deep south-oriented Missouri River valley eroded headward into the region. Under such conditions headward erosion of the south-oriented Silver Creek tributary valley from the much deeper south-oriented Missouri River valley would have caused floodwaters to carve shallow diverging and converging flood flow channels into the low relief and low gradient topographic surface to the north of the actively eroding Silver Creek valley head. Headward erosion of the deeper Missouri River valley would have eventually beheaded at least one of these shallow diverging and converging south-oriented flood flow channels. Because the Missouri River valley was much deeper than the flood flow channel(s) it beheaded water at the north end(s) of the beheaded channel(s) reversed its flow direction and moved in a north direction to the deeper Missouri River valley so as to create the north-oriented Elm Creek drainage route. Also, because the shallow south-oriented flood flow channels diverged and converged the newly formed north-oriented Elm Creek drainage route could capture south-oriented flood 
waters still moving in a south direction to the west of the newly reversed flood flow channel. These captured southoriented floodwaters eroded the south-oriented Elm Creek tributary valleys and supplied much of the water needed to erode the deep north-oriented Elm Creek valley. And as the Missouri River valley eroded headward this relatively simple beheading and reversal process was repeated over and over again.

Highest areas in the region seen in figure 2 are isolated and relatively small flat-topped hills located along the Elm Creek-Silver Creek and South Blackbird Creek-Bell Creek drainage divides. Figure 3 provides a detailed topographic map of an Elm Creek-Silver Creek drainage divide segment where a few of the isolated and small flat-topped hills can be seen and a similar hill along the Elm Creek-Missouri River drainage divide in the figure 3 northeast corner can also be seen. The top of each hill seen in figure 3 and of the highest points along the somewhat lower elevation South Blackbird Creek-Bell Creek drainage divide to the west have elevations of slightly more than 1400 feet (427 meters). The similarity of high points along each of the two drainage divides suggests before headward erosion of the deep valleys the south-oriented melt water floods flowed on a low relief and low gradient erosion surface with an elevation in this region slightly higher than 1400 feet (427 meters).

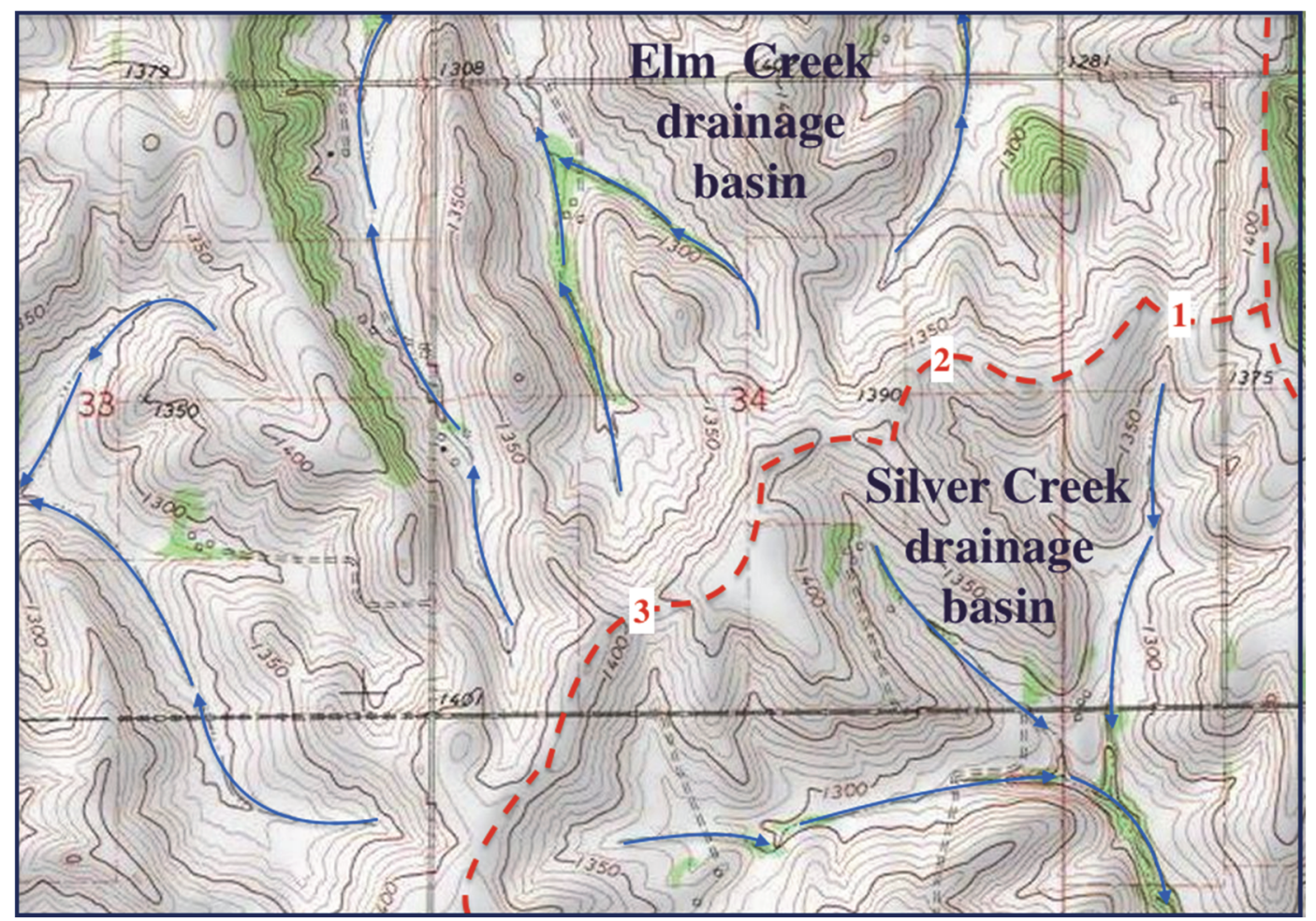

Figure 3. Modified detailed topographic map from the USGS National Map website showing an Elm Creek-

Silver Creek drainage divide segment. The dashed red line shows the drainage divide location and the red numbers identify drainage divide gaps discussed in the text. Sides of squares in the grid are 1 mile (1.6 kilometers) long. The contour interval is 10 feet ( 3 meters)

Headward erosion of the 400-foot (122-meter) deep or deeper south-oriented Missouri River valley and of the shallower south-oriented Silver Creek valley was into this 1400-foot (427-meter) high or higher low relief and low gradient topographic surface. Shallow diverging and converging south-oriented flood flow channels leading across the low relief and low gradient topographic surface to the actively eroding Silver Creek valley head were beheaded and reversed when Missouri River valley headward erosion reached the northern edge of figure 2 . Those beheaded and reversed flood flow channels had been moving floodwaters to the actively eroding south-oriented Silver Creek drainage basin and had just eroded valleys now seen as gaps between the flat-topped hills in figure 3 at locations marked by the red numbers 1,2, and 3. The floor of gap number 1 has an elevation of approximately 1374 feet (419 meters), of gap number 2 an elevation of approximately 1372 feet (418 meters), and of gap number 3 an elevation of approximately 1392 feet (425 meters) suggesting the flood flow was moving in channels ranging from approximately 20 to 40 feet (6-12 meters) deep. The deepest gap is found to the west of figure 3 and has a floor elevation of approximately 1356 feet (413 meters) and is approximately 55 feet (17 meters) deep.

When floodwaters in shallow flood flow channels to the north of the present day Elm Creek-Silver Creek drainage 
divide were reversed so as to move in a north direction toward the much deeper Missouri River valley they captured south-oriented floodwaters in adjacent shallow flood flow channels and water moving across divides between the flood flow channels. Because the flood flow channels diverged and converged the reversed flow channel captured floodwaters still moving in a south direction to the west of the actively eroding Missouri River valley head and to the north of the still actively eroding Bell Creek valley head. At that time Missouri River valley headward erosion had yet to behead and reverse flow on the South Blackbird Creek alignment and South Blackbird Creek valley erosion had yet to begin. As a result large volumes of south- and southeast-oriented water moving at elevations of slightly more than 1400 feet (422 meters) flowed from what is now the South Blackbird Creek drainage basin into what is now the Elm Creek drainage basin and helped to erode the north-oriented Elm Creek valley. Flow from the west to the newly reversed and rapidly eroding Elm Creek drainage basin ended when Missouri River valley headward erosion beheaded and reversed south oriented floodwaters in the South Blackbird Creek drainage basin (at location number 2 in figure 1). Steep gradients on both sides of the Elm Creek-Silver Creek drainage divide suggest the drainage reversal occurred when immense volumes of water still reached the drainage divide area and were able to erode deep valleys headward in both directions as water drained from the newly formed drainage divide to reach the newly eroded and much deeper Missouri River valley.

The South Blackbird Creek U-turn seen in the northwest corner of figure 2 was created after headward erosion of the deep Missouri River valley beheaded and reversed a shallow flood flow channel moving large volumes of water in a south direction along what is now the north-oriented South Blackbird Creek alignment to what was then the actively eroding south-oriented Bell Creek valley. Reversal of flow in that flood flow channel created what are now the South Blackbird Creek-Elm Creek and South Blackbird Creek-Bell Creek drainage divides and also captured large volumes of flood flow still moving in a south and southeast direction along what is now the southsoutheast oriented South Blackbird Creek headwaters segment seen in figure 2. Shallow gaps, similar to those illustrated in figure 3, are found along the South Blackbird Creek-Bell Creek drainage divide and again suggest that just prior to the drainage divide creation flood waters were flowing in 20 to 40 foot (6-12 meter) deep diverging and converging channels carved into a flood eroded topographic surface slightly higher than 1400 feet (422 meters). Just as erosion of the north-oriented Elm Creek valley and creation of the Elm Creek-Silver Creek drainage divide required immense floods to reach that drainage divide area equally large volumes of floodwaters are needed to explain erosion of the north-oriented South Blackbird Creek valley and creation of the South Blackbird Creek-Bell Creek drainage divide.

\subsection{Omaha Creek Barbed Tributaries}

Omaha Creek is another unusual north-oriented stream entering a southeast-oriented Missouri River valley segment (at location 3 in figure 1). South Omaha Creek originates to the west of the south-southeast oriented South Blackbird Creek headwaters (5 miles or 8 kilometers to the north and west of figure 2) and after flowing approximately one mile ( 1.6 kilometers) in a west direction turns to flow approximately 5 miles ( 8 kilometers) in a north direction to location 1 along the south edge of figure 4. At location 1 southeast-oriented North Omaha Creek joins north-oriented South Omaha Creek as a barbed tributary to form north-oriented Omaha Creek. Before reaching location 1 several other southeast-oriented tributaries (the largest of which is Cow Creek seen in the southwest corner of figure 4) also join north-oriented South Omaha Creek and as seen in figure 4 both southeastand southwest-oriented tributaries join north-oriented Omaha Creek. Between the north-oriented Omaha Creek drainage basin and the Missouri River valley is south-oriented North Blackbird Creek, which 4 miles (6.4 kilometers) to the south of figure 4 turns in an east direction to join north-oriented South Blackbird Creek at the Missouri River valley edge.

Wayne (1985) considered northeast Nebraska's parallel southeast-oriented streams including southeast-oriented North Omaha Creek and Cow Creek seen in figure 4, the southeast-oriented South Blackbird Creek segment seen in figure 2, and southeast-oriented Logan Creek (to the south and west of figures 2 and 4 ) to have formed along a retreating glacier margin. What Wayne's hypothesis cannot explain is why water in South Blackbird Creek, North Omaha Creek, Cow Creek, and other southeast-oriented Omaha Creek tributaries turns to flow in a north direction before entering the south-oriented Missouri River. However, the north-oriented Omaha Creek drainage route with its south-oriented tributaries can be explained if headward erosion of the 400-foot (122-meter) deep or deeper Missouri River valley beheaded and reversed flow in a much shallower south-oriented flood flow channel that had been supplying water to the southeast and south-southeast oriented Logan Creek valley (which drains to the Elkhorn River seen in figure 1). Such an explanation requires the south-oriented melt water floods to have been most intense where the large and deep Missouri River valley eroded headward along Nebraska's eastern border, yet significant south- and southeast-oriented melt water floods to have also been flowing across all of northeast Nebraska. 
Figure 5 provides a detailed topographic map showing the South Omaha Creek headwaters area approximately 5 miles ( 8 kilometers) to the south of the figure 4 south edge and also shows the Omaha Creek-Big Slough Creek drainage divide with Big Slough Creek being a south-southeast oriented tributary flowing to southeast-oriented Logan Creek (which flows to the Elkhorn River). Red numbers identify significant drainage divide gaps. The largest gap is identified by the number 1 and has a floor elevation of approximately 1360 feet (415 meters), a width of more than a mile (1.6 kilometers), and drainage divide elevations on either side rise to slightly over 1450 feet (442 meters). The size of this gap indicates that just before the Omaha Creek flow reversal south-oriented floodwaters moving to the Big Slough Creek and Logan Creek valleys had eroded a 90-foot (27.5 meter) deep or deeper channel into a low relief and low gradient topographic surface now represented by the drainage divide high points (note how the former topographic surface is gradually rising in a northward direction). The narrower gap at number 2 has almost the same floor elevation as the gap at the number 1 suggesting south-oriented water eroded both gaps at the same time. The gap at the number 3 has a slightly higher floor elevation, but is difficult to explain unless all three gaps were eroded at the same time with south-oriented flow at gap number 3 ending while southoriented flow was still moving through the gaps at numbers 1 and 2.

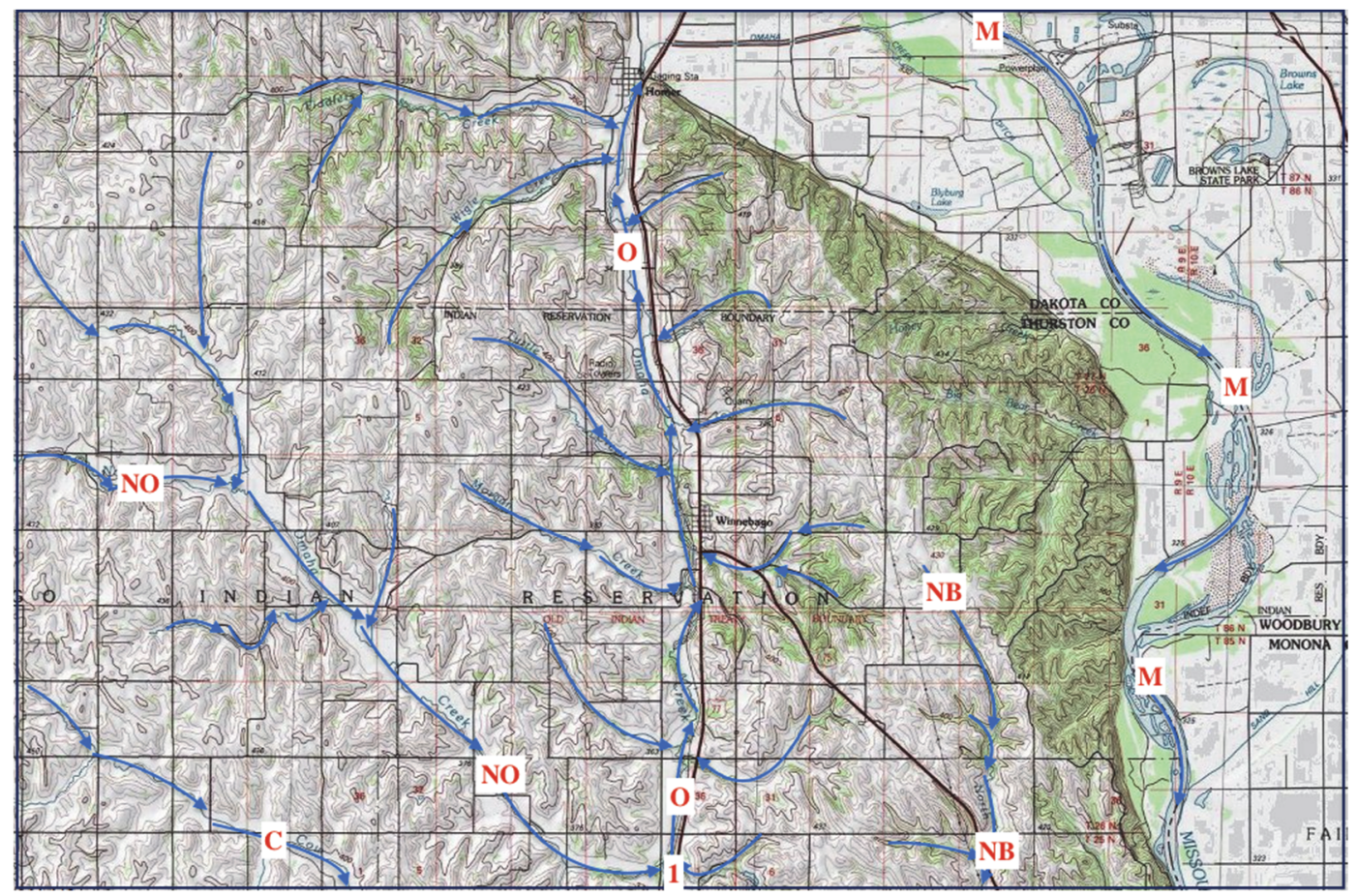

Figure 4. Modified topographic map from USGS National Map website. Blue arrows emphasize drainage routes identified by red letters as follows: C- Cow Creek, M-Missouri River, NB-North Blackbird Creek, NO-North Omaha Creek, and O-Omaha Creek. Sides of grid squares are 1 mile (1.6 kilometers) long and the contour interval is 10 meters ( 33 feet). Figure 4 is at location number 3 in figure 1

\subsection{Other Unusual North-Oriented Missouri River Tributaries}

Elm Creek, South Blackbird Creek, and Omaha Creek are by no means the only north-oriented streams in northeast Nebraska with south-oriented headwaters and/or tributaries flowing to the east-, southeast-, and south-oriented Missouri River. Proceeding upstream along the Missouri River Pigeon Creek is the next major north- and northeastoriented Missouri River tributary at location 4 in figure 1. Pigeon Creek begins as a north-oriented stream and turns in a northeast direction before entering the southeast-oriented Missouri River valley. Some north-oriented tributaries join the northeast-oriented Pigeon Creek segment and southeast-oriented tributaries flow to both the north- and northeast-oriented Pigeon Creek segments. Further the north-oriented Pigeon Creek headwaters are located a short distance to the north of the southeast-oriented North Omaha Creek headwaters and multiples gaps now located along the Pigeon Creek-North Omaha Creek drainage divide suggest large south-oriented floods once carved numerous diverging and converging shallow channels into what appears to have been a low gradient and low relief topographic surface.

Elk Creek joins the Missouri River as a southeast-oriented stream about 4 miles (6.5 kilometers) upstream from 
Pigeon Creek (slightly upstream from location 4 in figure 1) and also begins as a southeast-oriented stream, but for a significant percent of its route flows in a north or northeast direction. Like other north-oriented Missouri River tributaries multiple southeast-oriented tributaries join Elk Creek. Southeast-oriented Elk Creek headwaters are located immediately to the north and east of the southeast-oriented Middle Creek valley with Middle Creek flowing in a southeast and south direction to reach southeast-oriented Logan Creek (which flows to the Elkhorn River). Again multiple gaps notched into the Elk Creek-Middle Creek drainage divide suggest south-oriented floods carved shallow diverging and converging channels into what must have been a low gradient and low relief topographic surface.

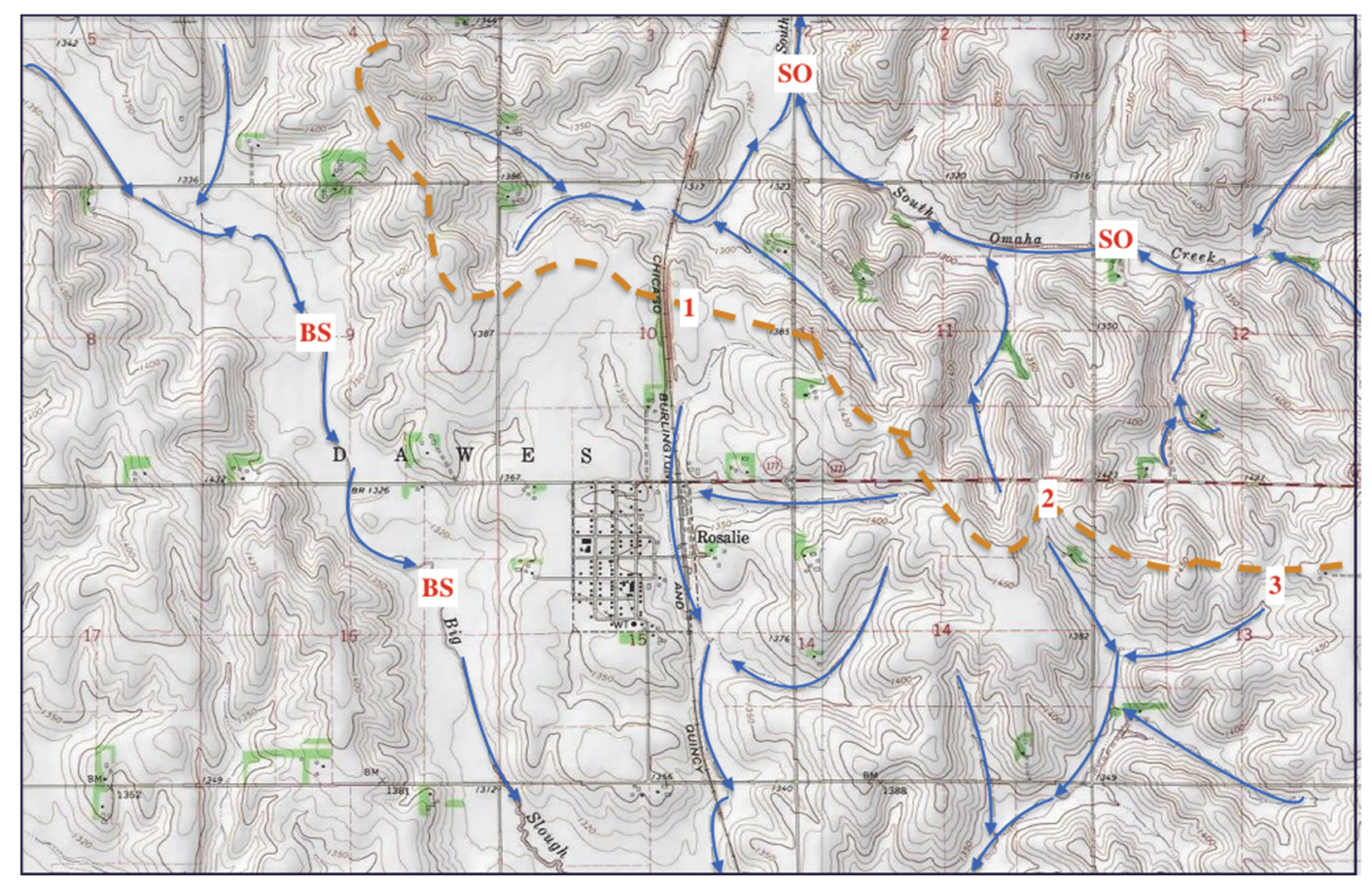

Figure 5. Modified topographic map of the South Omaha Creek (SO) headwaters area and the drainage divide with Big Slough Creek (BS). Blue arrows show drainage routes and directions and the dashed brown line shows the drainage divide location. Sides of squares in the grid are I mile (1.6 kilometers) long and the contour interval is 20 feet ( 6 meters)

A few miles (kilometers) upstream from Elk Creek southeast-oriented Aowa Creek enters the Missouri valley at location number 5 in figure 1 and 2 miles (3.2 kilometers) upstream from where it enters the Missouri River valley is joined by north- and northeast-oriented South Creek. To the west of South Creek Aowa Creek is joined by other northeast-oriented tributaries and also begins as a northeast-oriented stream. North-oriented drainage originates in the South Creek drainage basin as west- and north-oriented Rattlesnake Creek a short distance to the north of where Myrtle Creek now makes a U-turn from flowing in a northwest direction to flow in a south-southwest direction so as to reach the large southeast and south-southeast oriented Logan Creek valley (draining to the Elkhorn River). Northwest-oriented Myrtle Creek headwaters originate near southeast-oriented Middle Creek headwaters with Middle Creek eventually joining Logan Creek. A gap notched into the South Creek-Myrtle Creek drainage divide and shallower gaps in the Myrtle Creek-Middle Creek drainage divide suggest that prior to a reversal of flow water flowing in a south direction on the present day north-oriented Rattlesnake-South Creek alignment diverged at the Myrtle Creek U-turn location with one channel proceeding in a southeast direction while the other channel went in a south-southwest direction. Headward erosion of the large southeast and south-southeast oriented Logan Creek valley captured both of the diverging channels and eroded a deeper valley headward along the south-southwest oriented channel, which beheaded and reversed flow on what had been the southeast-oriented diverging channel to create the northwest-oriented Myrtle Creek headwaters seen today.

Bow Creek is the next major upstream north-oriented stream and enters the Missouri River valley just a short distance downstream from where the south-oriented James River now joins the Missouri River at location number 6 in figure 1. Wayne (1985) suggests "Bow Creek and its tributaries Norwegian Bow Creek and Bow Valley Creek [also known as West Bow Creek] describe arcs that seem to outline the margin of a small ice lobe that extended 
across the Missouri River valley into Nebraska from the James Valley lowland." Wayne also mentions that southeast and south-southeast oriented "Logan Creek heads at a broad triangular patch that contains considerable sand and gravel and points southeastward from [near] Bow Creek." He continues by saying the "succession of aligned drainage suggests that the last glacier to spread into eastern Nebraska retreated actively rather than by stagnation. Each of the ice-marginal streams surely represents either a standstill or a retreat and readvance of relatively small magnitude, as do many of the Wisconsin moraines of central Illinois and their ice-marginal streams, such as the Mackinaw, Vermillion, and Kankakee rivers (Lineback, 1979)."

Ice lobes extending across the present day Missouri River valley as Wayne suggests would have blocked water from the large upstream Missouri River drainage basin and the adjacent continental ice sheet and while glacial melt water almost certainly eroded the southeast and south-southeast oriented Logan Creek valley (draining to the Elkhorn River valley) as Wayne suggests, an alternate explanation better explains the Bow Creek and tributary drainage routes. At approximately the same time as the large and deep southeast- and south-oriented Missouri River valley was eroding headward around what is today Nebraska's northeast corner the Logan Creek valley was eroding headward in a north-northwest and northwest direction as both valleys were capturing massive southoriented melt water floods. Headward erosion of the deep Missouri River valley eventually beheaded and reversed flow in a shallow but important south- and southeast-oriented channel. Reversed flow in this newly reversed flood flow channel then eroded east-and northeast-oriented valleys from it to capture south- and southeast-oriented water still moving to the west of the actively eroding Missouri River valley head so as to form the Bow Creek, Norwegian Bow Creek, and West Bow Creek (or Bow Valley Creek) drainage routes Wayne describes.

\section{Discussion}

Highest points along northeast Nebraska drainage divides as previously mentioned have similar elevations suggesting that prior to erosion of stream and river valleys a low gradient and low relief topographic surface extended across the entire northeast Nebraska region. Elevations on this surface rose gradually in north and west directions. Since northeast Nebraska's highest points define this topographic surface the pre-stream valley erosion surface must either post date deposition of northeast Nebraska glacial tills and loess or have been formed as the glacial tills and loess were being deposited and the stream valleys were being eroded. The first interpretation implies one or more significant erosion cycles since glacial till and loess deposition and the second interpretation implies flood transport of the glacial till and loess materials, neither of which is consistent with published glacial till and loess interpretations.

To illustrate the situation Mason et al (2006) describe loess taken from cores drilled into the tops of Omaha area ridges (to the south of this paper's study area) showing the loess on top of coarser-grained glacial tills, which means all Pleistocene sediments had to have been deposited prior to formation of the pre-stream valley erosion topographic surface. Lugn (1939) describes the eastern Nebraska Pleistocene stratigraphy as follows, "The Kansan till where present, rests on [inter-till sands and] gravels, or unconformably on the Nebraskan till and gumbotill, which everywhere were greatly eroded before the deposition of either the inter-till sand and gravel or the Kansan till. Likewise erosion unconformities separate the Loveland [gravel, sand and loess clay] deposits from the underlying Kansan till and gumbotill, and the overlying yellowish Peoria loess." Evidence for a pre-stream valley erosion topographic surface existence (at least for a short period of geologic time) is good and immense southoriented melt water floods explain the northeast Nebraska barbed tributaries and other drainage patterns, but do immense south-oriented melt water floods also explain these eastern Nebraska Pleistocene deposits?

Ice sheet advances during the Nebraskan and Kansan glacial periods are usually considered to have transported and deposited northeastern Nebraska glacial tills. During the late $19^{\text {th }}$ century Chamberlin (1897) and others advocated glacial melt water floods as probable loess transport and deposition agents although almost all $20^{\text {th }}$ and $21^{\text {st }}$ century investigators regard North American loess as eolian deposits with the eastern Nebraska loess possibly derived from Missouri River valley fine-grained sediments. Yet the continental ice sheet melt history briefly described in Clausen's papers (e.g. 2017b, and 2018b) and locations of escarpments and coteau (or collapsed moraine) areas shown in figure 1 suggest the wide Missouri River valley must have eroded headward as massive south-oriented melt water floods flowed across the entire northeast Nebraska region. Clausen interprets the eastfacing Missouri Escarpment and the west-facing Prairie Coteau escarpment to have been carved when a giant south-oriented supra-glacial melt water river carved an ice-walled and bedrock-floored canyon into a decaying ice sheet. Such an immense south-oriented melt water river would have continued to flow in a south direction across what is now eastern Nebraska and would have carried significant quantities of ice-rafted glacially transported material.

The cited Clausen papers also describe how large southeast-oriented ice-marginal melt water floods carved what 
is now a large east-oriented valley between the Pine Ridge Escarpment and the Black Hills and how the Pine Ridge Escarpment was eroded as the that valley's south wall. To the east of the Black Hills southeast-oriented icemarginal melt water floods removed the east-oriented valley's north wall as that valley channeled the ice-marginal floods to flow in an east direction toward what is now the northeast Nebraska Missouri River valley. Southeastand east-oriented ice-marginal floods would have joined south-oriented melt water floods emerging from the icewalled and bedrock-floored canyon's mouth just to the north of northeast Nebraska. Supporting such an interpretation are the much wider Missouri River valley originating in that area and then continuing downstream along the Nebraska eastern border and the unusual northeast Nebraska drainage routes this paper describes. While not based on northeast Nebraska evidence Clausen's papers also suggest the large southeast-oriented ice-marginal floods were eventually diverted to the North Atlantic Ocean. This diversion triggered a climatic change causing the north-oriented floodwaters to freeze around decaying ice sheet remnants (now identified by the presence of collapsed moraines such as those on the Missouri Coteau and Prairie Coteau uplands) so as to create a new continental ice sheet.

\section{Conclusions}

Northeast Nebraska's north-oriented tributaries to the south-oriented Missouri River with south-oriented barbed tributaries originated during immense south-oriented melt water floods. South-oriented floods emerged from the mouth of what was probably a huge ice-walled and bedrock-floored canyon (now defined by eastern South Dakota's east-facing Missouri Escarpment and west-facing Prairie Coteau escarpment) that a large south-oriented supra-glacial melt water river had sliced into a decaying continental ice sheet's surface. As the deep Missouri River valley eroded headward around what is now Nebraska's northeast corner immense southeast-oriented ice-marginal melt water floods were gradually funneled toward that deep valley head as a large valley (the Pine Ridge Escarpment is its south wall) eroded westward across southern South Dakota and into eastern Wyoming while the southeast-oriented ice-marginal floodwaters it was capturing removed that valley's north wall almost as fast as the valley was being eroded. The south-oriented floods eventually merged with the southeast-oriented floods where the James River now joins the Missouri River and where the Missouri River's much wider valley now begins.

Prior to headward erosion of the deep Missouri River valley the large southeast- and south-oriented melt water floods flowing across northeast Nebraska had created a low relief and low gradient topographic surface over which the massive flood flow moved. The deep Missouri River valley and its south- and southeast-oriented tributary valleys eroded headward into this low relief and low gradient topographic surface with south-oriented floodwaters carving shallow diverging and converging channels into the upstream low relief and low gradient topographic surface as the floodwaters moved toward the much deeper and actively eroding south-oriented valley heads. Headward erosion of the deep Missouri River valley periodically beheaded the newly formed and much shallower low gradient south-oriented flood flow channels causing water at north ends of the beheaded flood flow channels to reverse flow direction so as to move toward the much deeper and newly eroded Missouri River valley and to create what are today drainage divides between north-oriented and south-oriented northeast Nebraska drainage basins.

The immense volumes of south-oriented floodwaters moving across northeast Nebraska's low relief and low gradient topographic surface and the shallow diverging and converging channels eroded into that surface enabled reversed flow on each newly beheaded and reversed flood flow channel to capture water still moving in south directions on either side of the newly reversed flood flow channel. Such captures provided the water needed to erode deep north-oriented valleys headward from the newly eroded Missouri River valley and deep south-oriented tributary valleys headward from the newly eroded and deep north-oriented Missouri River tributary valleys. These conclusions strongly suggest most if not all northeast Nebraska glacial tills and loess deposits are probably flood transported and deposited materials, which is quite different from previously published interpretations. Further work is needed to determine if and how northeast Nebraska glacial tills and loess deposits can be reinterpreted as glacial melt water flood transported and deposited materials.

\section{Acknowledgements}

During the mid and late 1960s Arthur Strahler then at Columbia University and Brainerd Mears at the University of Wyoming introduced the author to numerous unsolved drainage history problems. The Missouri River drainage basin landforms origin research project was first done while employed as a faculty member at Minot State University (North Dakota) where other faculty members and library staff members assisted in developing and providing access to needed topographic map collections.

\section{References}

Aber, J. S. (1982). Two-ice-lobe model for Kansan glaciation. Transaction of the Nebraska Academy of Science, 
$10,25-29$.

Alden, W. C. (1932). Physiography and glacial geology of eastern Montana and adjacent areas. United States Geological Survey Professional Paper, 174, 133p.

Bishop, P. (1995). Drainage rearrangement by river capture, beheading, and diversion. Progress in Physical Geography, 19, 449-473.

Bluemle, J. P. (1991). The Face of North Dakota: Revised Edition: North Dakota Geological Survey. Educational Series, 21, 178p.

Brophy, J. A., \& Bluemle, J. P. (1983). The Sheyenne River: its geologic history and effects on Lake Agassiz: in Teller, J. T. and Clayton, L., editors (1983). Glacial Lake Agassiz. Geological Association of Canada Special Paper, 26, 173-186.

Burchett, R. R., Dreeszen, V. H., Souders, V. L., \& Prichard, G. E. (1988). Bedrock geologic map showing configuration of the bedrock surface in the Nebraska part of the Sioux City 1 degree $\mathrm{x} 2$ degrees quadrangle: United States Geological Survey Miscellaneous Investigations Series Map I-1879.

Chamberlin, T. C. (1897) Supplementary hypothesis respecting the origin of the loess of the Mississippi valley. Journal of Geology, 5(8), 795-802.

Clausen, E. (2017a). Origin of Little Missouri River-South Fork Grand River and nearby drainage divides in Harding County, South Dakota and Adjacent Eastern Montana, USA. Open Journal of Geology, 7, 1063-1077.

Clausen, E. (2017b). Using map interpretation techniques for relative dating to determine a western North Dakota and South Dakota drainage basin formation sequence, Missouri River drainage basin, USA. Journal of Geography and Geology, 9(4), 1-18.

Clausen, E. (2018a). Probable deep erosion by continental ice sheet melt water floods: Chalk Buttes area of Carter County, Montana, USA. International Journal of Geography and Geology, 7(1), 14-26.

Clausen, E. (2018b). Belle Fourche River-Cheyenne River drainage divide area in the Wyoming Powder River Basin analyzed by topographic map interpretation methods, USA. Journal of Geography and Geology, 10(2) $1-16$.

Flint, R. F. (1955). Pleistocene geology of eastern South Dakota: United States Geological Survey Professional Paper, 262, 173p.

Flint, R. F. (1971). Glacial and Quaternary geology: New York, John Wiley \& Sons, Inc., 892 p.

Horberg, L., \& Anderson, R. C. (1956). Bedrock topography and Pleistocene glacial lobes in central United States. Journal of Geology, 64, 101-116.

Lineback, J. A. (1979). Quaternary deposits of Illinois: Illinois Geological Survey Map, MISCMAPquat.

Lugn, A. L. (1939). Nebraska in relation to problems of Pleistocene stratigraphy. American Journal of Science, 237(12), 851-884.

Mason, J. A., Bettis, E. A., Roberts, H. M., Muhs, D. R., \& Joeckel, R. M. (2006). AMQUA Pre-Meeting Field Trip 1: Last glacial loess sedimentary system of eastern Nebraska and western Iowa: in Mandel, R, D. editor, Guidebook of the $18^{\text {th }}$ Biennial Meeting of the American Quaternary Association: Kansas Geological Survey Technical Series, 21, 1-1 to 1-20.

McMillan, J. N. (1973). Shelves of the Labrador Sea and Baffin Bay, Canada. Canadian Society of Petroleum Geologists Memoir, 1, 473-515.

Pederson, D. T. (2001). Stream piracy revisited: a groundwater sapping solution: GSA Today 11 (9) 4-10.

Sears, J. W. (2013). Late Oligocene-early Miocene Grand Canyon: A Canadian connection? GSA Today, 23(11), 4-10.

Stanley, K. O., \& Wayne, W. J. (1972). Epeirogenic and climatic controls of Early Pleistocene fluvial sediment dispersal in Nebraska. Bulletin of the Geological Society of America, 83(3), 675-690.

Sugden, D. E. (1976). A case against deep erosion of shields by continental ice sheets. Geology: 4, 580-582

Thornbury, W.D. (1965). Regional Geomorphology of the United States: John Wiley and Sons, New York, 609 p.

United States Geological Survey (USGS) National Map. Retrieved form https://viewer.nationalmap.gov/advanced-viewer/ 
Wayne, W. J. (1985). Drainage patterns and glaciations in eastern Nebraska. TERQUA Symposium Series, 1, 111117.

Wayne, W. J. (1987). The Platte River and Todd Valley, near Fremont, Nebraska; in North Central Section of the Geological Society of America, Centennial Field Guide, v. 3, Biggs, D.L., editor: Geological Society of America, 19-22.

White, W. A. (1972). Deep erosion by continental ice sheets. Geological Society of America Bulletin, 83(4) 10371056.

\section{Copyrights}

Copyright for this article is retained by the author(s), with first publication rights granted to the journal.

This is an open-access article distributed under the terms and conditions of the Creative Commons Attribution license (http://creativecommons.org/licenses/by/4.0/). 